\title{
Being a scientist during covid-I9 pandemic: does guided inquiry affect students' creative thinking skills?
}

\section{Linda Tri Antika iD*, Atikutul Mukarromah}

Department of Biology, Faculty of Science Education, Universitas Islam Madura

"Corresponding author: lindatriantika@gmail.com

\begin{abstract}
Article Info
Article History:

Received 29 September 202I

Revised 29 October 2021

Accepted I6 November 202I

Published 30 November 202I

\section{Keywords:}

Guided inquiry

Creative thinking skills

HOTS

Pandemic

\section{ABSTRACT}

Guided inquiry learning encourages students to be more active in learning so that students' creative thinking skills can be developed. Guided inquiry learning model will assist students in empowering creative thinking skills. Creative thinking skills are described as mental activities that foster original ideas and new understandings. This study aimed to determine the effect of the guided inquiry learning model on the creative thinking skills of Class X MA Miftahul Ulum Bettet Pamekasan. The population in the study were all students of class X MA Miftahul Ulum Bettet Pamekasan second semester 2020/202I, while the samples used were class X IPA B and IPA C. The experimental class and control class each consisted of 20 students. This research is a quantitative research with quasi-experimental research method with pretest posttest nonequivalent pretestposttest control group design. The results of this study indicated that guided inquiry has a significant effect on creative thinking skills. Guided inquiry learning model can be a reference in learning (especially in biology) to empower students' thinking skills.
\end{abstract}

Copyright (C) 202I, Antika \& Mukarromah This is an open access article under the CC-BY-SA license

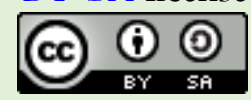

Citation: Antika, L.T., \& Mukarromah, A. (202I). Being a scientist during covid-I9 pandemic: does guided inquiry affect students' creative thinking skills?. JPBIO (Jurnal Pendidikan Biologi), 6(2), 272-280. DOI: https://doi.org/I0.31932/jpbio.v6i2.I424

\section{INTRODUCTION}

Education is a learning process in which students accept and understand knowledge as part of themselves, and process it for mutual progress (Sukma et al., 2016). Biology education is concerned with how to find out and understand about in a systematic way. It can be said that learning biology is not only a collection of knowledge namely facts, concepts, and principles, but also a discovery process, so that students have to think creatively (Neka et al., 2019). In addition, science and technology that is developing rapidly has an impact on changes in various aspects of human life which can cause various problems, especially in education. Only individuals who have habit to think critically and creatively will be able to survive productively in competition and open 
opportunities and challenges (Sudarisman, 20I2). Sadly, education in the world, especially Indonesia, is facing challenges in the form of the Covid-I9 pandemic which changes the face-toface education process into distance learning, or learning from home (Churiyah et al., 2020). In addition, students are required to have self-regulated learning to achieve maximum learning outcomes. The role of parents is also important in learning during this pandemic.

However, the facts showed that education in Indonesia was currently still low. According to the 20II TIMSS survey, conducted by The International Association for The Evaluation and Educational Achievement (IAE), Indonesia is in position 36 out of 40 countries (Murtiyasa, 20I5). The problem of learning, especially in Indonesia, is the lack of students' abilities, and one of the causes is that learning is only giving concepts and facts to students through lectures. In fact, biology has been very developed, so that students are not only given concepts and facts, but they also have to be able to find out for themselves about these concepts and facts (Susanti et al., 2017).

The results of initial observations on November I5, 2020 in class X IPA MA Miftahul Ulum Bettet showed that the implementation of learning still tends to be conventional which was dominated by the lecture method. During the learning process, students tended to focus on aspects of remembering which is a low order of thinking. This condition showed that the learning process did not empower creative thinking aspects. The results of the second observation on December I9, 2020 also showed that student activity was still low, meaning that students in learning tended to be listeners (passive). In fact, in 2Ist century education, it demands good quality human resources and is able to compete globally. Characteristics of good quality human resources are able to manage, use, and develop thinking skills. Skills that are in accordance with the demands of the 2Ist century are the critical thinking skills, creative thinking skills, collaboration, and communication (BSNP, 2010). As for this study, the researchers focused on two skills, namely creative thinking skills. The 2018 Program for International Student Assessment (PISA) stated that students have low reasoning aspects. The reasoning aspect includes critical, logical, systematic, creative, and objective thinking skills (Diani et al., 2019). On the aspect of creative thinking skills, it was stated in another source that Indonesian students still have less advanced creative thinking skills compared to international students (Happy \& Widjajanti, 20I4).

Creative thinking is a mental activity that generates original ideas and new understandings. Creative thinking enables students to explore problems systematically, face many challenges in an organized way, create innovative questions, and create solutions originally (Johnson, 20II). Creative thinking skills are one of the goals that must be achieved in learning at school. Creativity or creative thinking can not appear by itself but it takes practice. Teachers are required to be able to train students' creative thinking skills by bringing up life problems. Creative thinking skills are very important to prepare students to compete globally (Meika \& Sujana, 2017). Creative thinking skills need to be trained, because this skill can make students fluent and flexible in thinking, can see a problems from various points of view. Creative thinking skills do not just appear but there needs to be a trigger for creative thinking skills that students can have by providing chances for students to be maximally involved in investigating something systematically, critically, logically, and analytically so that students are able to formulate their own findings with confidence (Srifujiyati et al., 2018)

Because of the importance of creative thinking skills, it is necessary to make efforts to empower these skills in the learning process with a certain model. Guided inquiry is one of the learning models that can be used. Guided inquiry is a model that maximally involves all students' abilities to search and investigate existing events or phenomena systematically, logically, and critically, so that they can formulate their own findings. In addition, the level of understanding obtained by students is directly in the process of finding answers to existing problems and directly practicing (Amijaya et al., 20I8). Inquiry is a core part of contextual-based learning activities. The 
knowledge gained is expected to be not just the result of remembering facts, but the results of their own discoveries. In guided inquiry, the teacher still has a guiding role in learning (Trianto, 2012).

Previous research has shown that there was an effect of guided inquiry on students' creative thinking skills (Neka et al., 2019); (Susanti et al., 2017); (Amaliah et al., 2019). Learning models using guided inquiry can improve creative thinking skills (Putra et al., 2016). In other studies, the use of guided inquiry models greatly influenced students' creative thinking skills in biology lessons than direct learning models or without using guided inquiry models (Neka et al., 2019). In fact, inquiry can improve scientific understanding, be productive in creative thinking, and students become skilled in obtaining and analyzing information (Trianto, 20I2). However, similar research during the Covid-I9 pandemic has not been disclosed, so this research needs to be carried out in order to see whether guided inquiry gives a positive effect on students' creative thinking skills.

\section{RESEARCH METHODS}

\section{Research Design}

This research is a quantitative study with a quasi-experimental research design with a nonequivalent pretest-posttest control group design. This study aimed to determine the effect of the guided inquiry learning model on critical thinking and creative thinking skills of students at MA Miftahul Ulum Bettet Pamekasan.

\section{Population and Samples}

The population in this study were all students of class X at MA Putri Miftahul Ulum Bettet Pamekasan. The sample used was class X IPA B MA Miftahul Ulum Bettet Pamekasan which consisted of 20 students and class X IPA C which consisted of 20 students. Determination of the sample in this study was done by random sampling technique.

\section{Instruments}

The research instrument used is the creativity assessment rubric. The data obtained from the results of the research was the student's creativity score data before and after the research was carried out. Table I presents creative thinking skills assessment rubric.

Table I. Creative thinking skills assessment rubric

\begin{tabular}{|c|c|c|}
\hline Aspect & Score & Criteria \\
\hline \multirow{5}{*}{ Fluence } & 4 & Give more than one correct answer and complete reasons. \\
\hline & 3 & Give more than one correct answer, but the reason is not quite right. \\
\hline & 2 & Gives one correct answer, but the reason is incorrect. \\
\hline & I & Gives one answer, but does not give reasons. \\
\hline & 0 & No answer. \\
\hline \multirow{7}{*}{ Fexibility } & 4 & $\begin{array}{l}\text { Provide more than one answer that is diverse/different accompanied by } \\
\text { complete reasons. }\end{array}$ \\
\hline & 3 & $\begin{array}{l}\text { Give more than one answer that varies / different, but the reason is not } \\
\text { quite right. }\end{array}$ \\
\hline & 2 & Gives one answer, but the reason is incorrect. \\
\hline & $\mathrm{I}$ & Gives one answer, but does not give reasons. \\
\hline & 0 & No answer. \\
\hline & 4 & $\begin{array}{l}\text { Provide answers in their own way in accordance with the concept in } \\
\text { question completely and accurately. }\end{array}$ \\
\hline & 3 & $\begin{array}{l}\text { Give answers in their own way according to the concept in question, but } \\
\text { not complete and precise. }\end{array}$ \\
\hline
\end{tabular}




\begin{tabular}{lll}
\hline \multirow{2}{*}{ Originality } & 2 & $\begin{array}{l}\text { Give answers in their own way, but not in accordance with the intended } \\
\text { concept and inappropriate. }\end{array}$ \\
\cline { 2 - 3 } & I & Giving answers in his own way but not understandable. \\
\hline 0 & No answer. \\
\hline 4 & Describe solutions to given problems in detail and correctly. \\
\hline 3 & Describe solutions to given problems in detail, but not yet complete. \\
\hline 2 & Describe solutions to given problems, but lacks detail. \\
\hline Elaboration & 0 & Describe solutions to given problems, but not in detail. \\
\hline
\end{tabular}

\section{Procedures}

This research was conducted on second semester 2020 students in biology subjects. This research includes two stages, namely preparation and implementation. The preparations carried out were conducting observations to schools, licensing research, compiling test questions and answers, compiling learning tools, such as syllabus, lesson plans, student worksheets, scoring rubrics, test kits, and observation sheets on the implementation of guided inquiry syntax. The implementation phase was carried out by observing at the school where the research was conducted, conducting a pretest, carrying out the learning process in accordance with the lesson plan based on guided inquiry, and a posttest to determine students' creative thinking skills. The procedures of the research can be seen in Figure I.

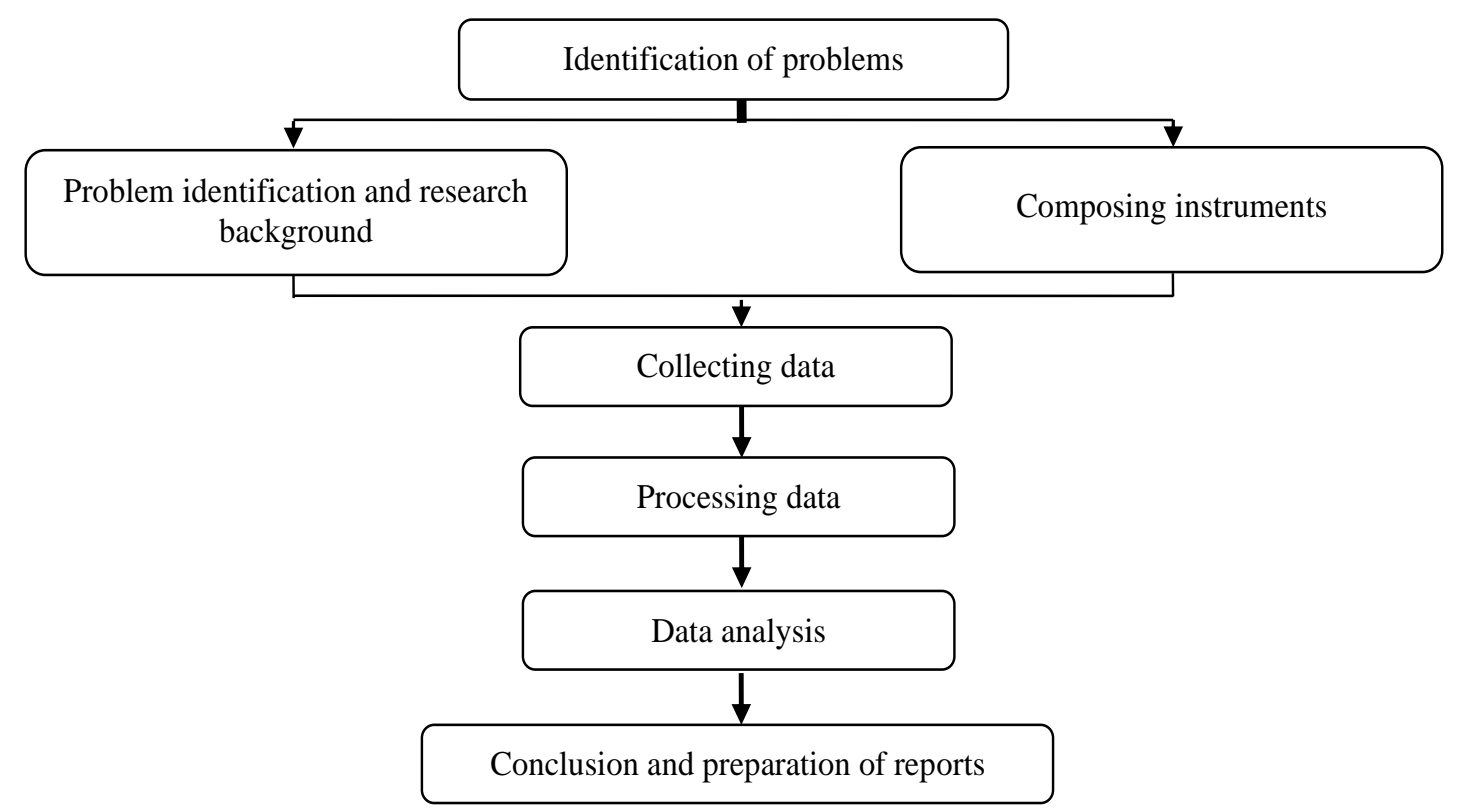

Figure I. The procedures of the research

\section{Data Analysis}

Data analysis was carried out with the help of the Jamovi I.6.23 program. Before testing the research hypothesis, the normality and homogeneity of the data were first tested. The research hypothesis was tested using the Kruskall-Wallis non-parametric One-Way ANOVA test ( $a=$ $0.05)$. 


\section{RESULTS}

\section{Description of Research Data}

The research data was obtained from the sample class data, namely class X MA Miftahul Ulum Bettet. Data were obtained from two classes, namely class X IPA B as an experimental class consisted of 20 students, while class X IPA C as a control class consisted of 20 students. The data in this study include data on students' creative thinking skills based on pretest and posttest data. The data on the mean score of creative thinking skills of experimental and control class students can be seen in Table 2 .

Table 2. Mean creative thinking skills of the experimental and control classes

\begin{tabular}{llc}
\hline & Class & Post test \\
\hline $\mathrm{N}$ & Experiment & 20 \\
& Control & 20 \\
Mean & Experiment & 60.9 \\
\multirow{3}{*}{ Standard deviation } & Control & 55.5 \\
& Experiment & 4.48 \\
& Control & 3.07 \\
\hline
\end{tabular}

Table 2 shows that the mean in the experimental class is 60.9 and in the control class is 55.5 and shows that the standard deviation value in the experimental class is 4.48 and the control class is 3.07. The data above provides additional information in the form of increasing creative thinking skills in the control class by $26.07 \%$. While the increase in creative thinking skills in the experimental class was 3I.I8\%.

\section{Test Assumptions of Research Data}

Before conducting the test, the analyzed data must meet the requirements of the ANCOVA assumption which includes covariate homogeneity and the slope or slope of the regression line between the covariate (pretest) and the dependent variable (creative thinking). The results of covariate homogeneity and the slope or slope of the regression line between covariates are shown in Table 3 and Figure 2.

Table 3 shows $p$ value of $0.002(p<0.05)$, means there is a difference in the pretest variance in the two classes, so it can be said that the assumption of covariate homogeneity is not met. While Figure I shows that the two lines show unequal directions (not parallel). These results confirmed that the assumption test of the slope of the regression line between the covariates and the dependent variable in both classes is not met.

Table 3. Summary of homogeneity test results

\begin{tabular}{lccccc}
\hline & Sum of Squares & $\mathrm{df}$ & Mean Square & F & P \\
\hline Class & 52.9 & I & 52.90 & I I.4 & 0.002 \\
Residuals & I77.I & 38 & 4.66 & & \\
\hline
\end{tabular}




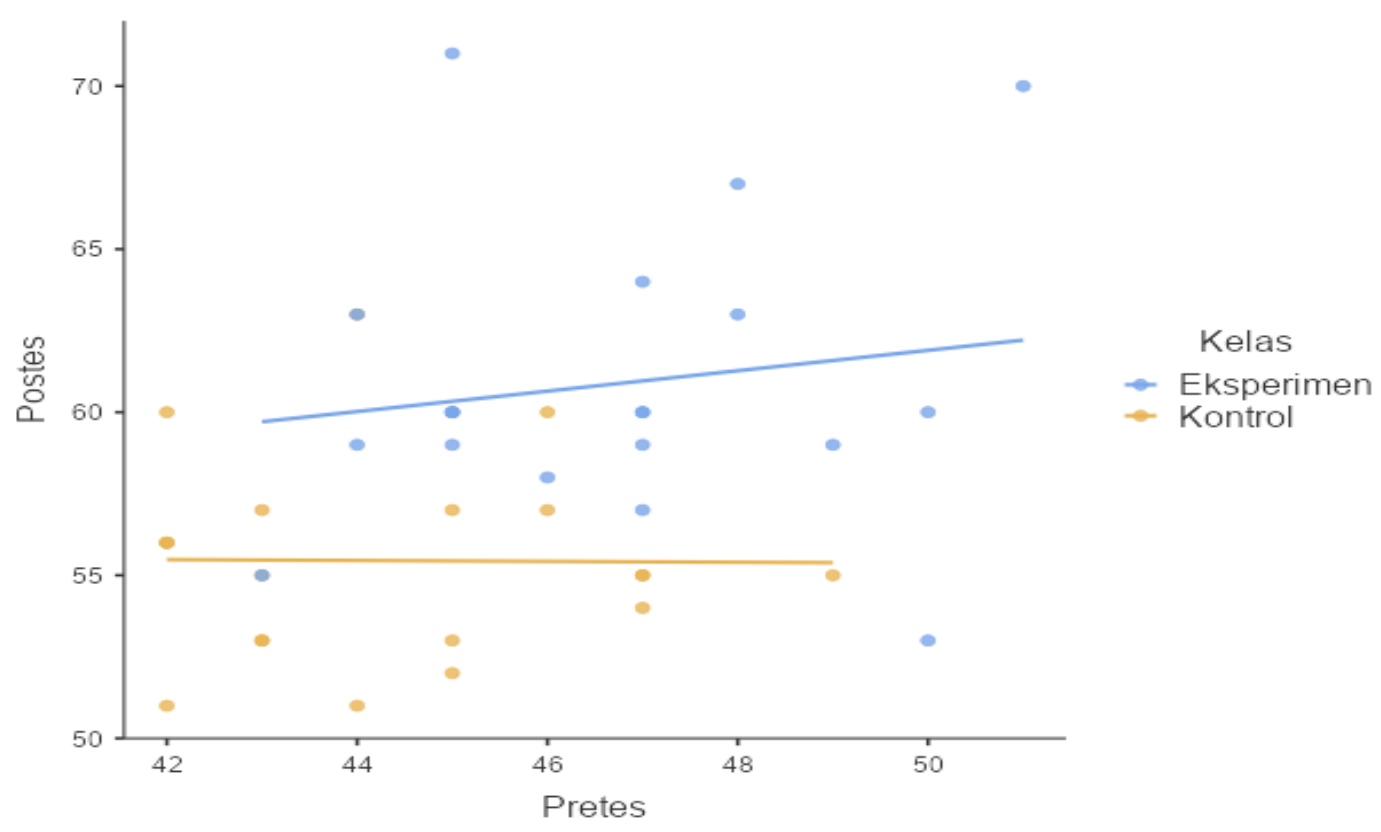

Figure 2. The results of the slope test or the slope of the regression line between covariates

\section{Hypothesis Test Results}

In the previous explanation, it shows that the assumption of normality of the data is not met and the homogeneity of variance is met, thus using the Kruskall-Wallis non-parametric statistical technique. The assumption of covariate homogeneity is not met and the slope of the covariate regression line with the dependent variable in both classes is not parallel, so the ANCOVA technique cannot be used. This technique tests whether there is a difference in the posttest mean of the two classes without correction from the pretest which can be seen in Table 4 .

Table 4. One-Way ANOVA (Non-parametric)

Kruskal-Wallis

\begin{tabular}{lllc}
\hline & $\boldsymbol{\chi}^{\mathbf{2}}$ & $\mathrm{df}$ & $\mathrm{P}$ \\
\hline Postes & $\mathrm{I} 4.7$ & $\mathrm{I}$ & $<.00 \mathrm{I}$ \\
\hline
\end{tabular}

Table 4 shows that the $\mathrm{p}$ value is $<.00 \mathrm{I}(\mathrm{p}<0.05)$, there is a difference in the posttest mean of the two classes. Especially for the Kruskall-Wallis test on two samples, the magnitude of the effect $\eta^{2}$ is calculated by the formula $\eta^{2}=\chi^{2} / \mathrm{n}$. Therefore, $\eta^{2}=I 4.7 / 40=0.368$ (small effect). In other words, there is a significant effect of the guided inquiry learning model on creative thinking skills with a small effect.

\section{DISCUSSION}

The results of the analysis show that the significance value is $0.000(p<0.05)$, Ho was rejected and $\mathrm{H}_{\mathrm{I}}$ is accepted, meaning that there is a significant difference in creative thinking skills from the two teaching methods. In other words, "there is a significant effect of the guided inquiry learning model on the creative thinking skills of the X Class of MA Miftahul Ulum Bettet Pamekasan". The mean pretest and posttest of students' creative thinking skills in the experimental class showed that in the experimental class there was an increase in the mean creative thinking skills from the results of the pretest and posttest. The mean of the pretest and posttest of creative 
thinking skills class increased by $31.18 \%$. While the control showed the mean score of creative thinking skills from the pretest and posttest of $26.07 \%$.

The results of this study are in line with previous research which explained that there was a significant influence between the guided inquiry learning model on students' creative thinking skills (Susanti et al., 2017). The results of this study provided facts about the importance of creative thinking skills, so that it becomes the basis that students' creative thinking skills need to be empowered in learning. One of the efforts to empower students' creative thinking skills is to use a learning model as a medium. The learning model that is very relevant in empowering students' creative thinking skills is guided inquiry.

Guided inquiry is a learning model in which the teacher provides instructions to students, so the teacher can encourage students to have experience and conduct experiments that allow students to find principles for themselves (Lovisia, 2018). Creative thinking skills are a thought process to reveal new correlations, see things from new perspectives, and form new combinations of two or more concepts that have been previously mastered. Creative thinking skills help students create new ideas based on the knowledge they already have to solve problems from different perspectives. The lack of people who think creatively is characterized by low innovation and new creations by the general public (Yunianta et al., 2012).

Creative thinking is a habit of the mind that is trained to pay attention to intuition, activate the imagination, reveal new possibilities, open up amazing points of view, and generate unexpected ideas. Students are accustomed to thinking creatively seeing new possibilities, not limitations, daring to experiment without fear of making mistakes and following their conscience and enriching the lives of other students and even the earth with its authenticity (Johnson, 20II). Students' creative thinking skills need to be improved by providing facilities and opportunities for students to develop their creativity. Creative thinking skills developed in learning include aspects of fluent thinking, flexible thinking, original thinking, and elaboration thinking. One effort to improve students' creative thinking in biology subjects is to use a guided inquiry learning model (Tumurun et al., 2016)

The explanation of guided inquiry has a significant effect on students' creative thinking skills, it is emphasized by several researchers that the learning model using guided inquiry can improve creative thinking skills (Putra et al., 2016); (Malau et al., 2019). Guided inquiry is a learning model that can train students' skills in carrying out the investigative process to collect data in the form of facts and process these facts, so that students are able to build conclusions independently to answer questions or problems posed by the teacher by finding their own solutions. Meaningful learning will be created because students experience themselves in solving problems through experience (Bell et al., 2010). Other research reveals that guided inquiry improves students' creative thinking skills (Oktavia, 2020).

This study concluded that the creative thinking skills of the experimental class students (guided inquiry learning model) was better than the control. This can be seen in the results of this study which have been described in detail previously. Therefore, the guided inquiry learning model can be a reference in learning (especially biology subjects) in order to empower students' thinking skills.

\section{CONCLUSION}

This study revealed that there was a significant effect of the guided inquiry learning on the creative thinking skills of class X MA Miftahul Ulum Bettet Pamekasan students. Guided inquiry can be used as an alternative to the best learning model in accordance with the 2013 curriculum with a scientific approach. The guided inquiry model can be used in any learning material, especially biology. 


\section{ACKNOWLEDGMENT}

We would like to thank Moch. Haikal, S.Si., M.Pd and Lukluk Ibana, S.Pd., M.Pd who have contributed in improving data analysis and content quality.

\section{REFERENCES}

Amaliah, A. M., Rahman, A. H., \& Ratu, T. (2019). Pengaruh Model Pembelajaran Inkuiri Terbimbing Terhadap Keterampilan Berpikir Kreatif dan Keterampilan Proses Sains Peserta Didik. QUARK: Jurnal Inovasi Pembelajaran Fisika Dan Teknologi, 2(I), 5-9. Retrieved from_https://doi.org/I0.29303/ jpm.vI3.i2.468

Amijaya, L. S., Ramdani, A., \& Merta, I. W. (2018). Pengaruh Model Pembelajaran Inkuiri Terbimbing Terhadap Hasil Belajar Dan Kemampuan Berpikir Kritis Peserta Didik. Jurnal Pijar Mipa, I3(2), 94. Retrieved from_https://doi.org/I0.29303/jpm.vI3i2.468

Bell, T., Urhahne, D., Schanze, S., \& Ploetzner, R. (2010). Collaborative inquiry learning: Models, tools, and challenges. International Journal of Science Education, 32(3), 349-377. Retrieved from_https://doi.org/I0.1080/0950069080258224I

Churiyah, M., Sholikhan, S., Filianti, F., \& Sakdiyyah, D. A. (2020). Indonesia Education Readiness Conducting Distance Learning in Covid-I9 Pandemic Situation. International Journal of Multicultural and Multireligious Understanding, 76), 49I. Retrieved from https://doi.org/I0.184I5/ijmmu.v7i6.1833

Diani, R., Herliantari, H., Irwandani, I., Saregar, A., \& Umam, R. (2019). Search, Solve, Create, and Share (SSCS) Learning Model: The Impact on the Students' Creative Problem-Solving Ability on the Concept of Substance Pressure. Jurnal Penelitian Fisika Dan Aplikasinya (JPFA), Q(I), 65. Retrieved from_https://doi.org/I0.26740/jpfa.v9nI.p65-77

Happy, N., \& Widjajanti, D. B. (20I4). Keefektifan Pbl Ditinjau Dari Kemampuan Berpikir Kritis Dan Kreatif Matematis, Serta Self-Esteem Siswa Smp. Jurnal Riset Pendidikan Matematika, $I(\mathrm{I}), 48$. Retrieved from_https://doi.org/I0.2I83I/jrpm.viiI.2663

Johnson, E. B. (20II). Contextual Teaching Learning. Menjadikan Kegiatan Belajar Mengajar Mengasyikkan dan Bermakna. Kaifa.

Lovisia, E. (2018). Pengaruh Model Pembelajaran Inkuiri Terbimbing Terhadap Hasil Belajar. SPEJ (Science and Physics Education Journal), 2(I), I-IO. Retrieved from https://doi.org/I0.3I539/spej.v2iI.333

Malau, S. M., Motlan, Sirait, M., \& Lubis, R. H. (2019). The Effect of Guided Inquiry Learning Model and Creativity on Students Science Process Skills. Journal of Transformative Education and Educational Leadership, I(2), 29-37.

Meika, I., \& Sujana, A. (2017). Kemampuan Berpikir Kreatif Dan Pemecahan Masalah Matematis Siswa Sma. Jurnal Penelitian Dan Pembelajaran Matematika, IO(2), 8-I3. Retrieved from https://doi.org/I0.30870/jppm.vI0i2.2025

Murtiyasa, B. (2015). Tantangan Pembelajaran Matematika Era Global. Prosiding Seminar Nasional Matematika Dan Pendidikan Matematika UMS, 3, 28-47.

Neka, I. K., Marhaeni, A. A. I. ., \& Suastra, I. W. (2019). Pengaruh Model Pembelajaran Inkuiri Terbimbing Berbasis Lingkungan Terhadap Keterampilan Berpikir Kreatif Dan Penguasaan Konsep Ipa Kelas V Sd Gugus Viii Kecamatan Abang. Jurnal Pendidikan Dasar Ganesha, 5(I), I24383. Retrieved from_https://media.neliti.com/media/publications/I24383-IDpengaruh-model-pembelajaran-inkuiri-terb.pdf

Oktavia, R. S. (2020). Implementation of Guided Inquiry-Based Learning Model To Improve Students' Creativity Thinking Skill. JPPS (Jurnal Penelitian Pendidikan Sains), 9(I), 1756. Retrieved from_https://doi.org/I0.26740/jpps.v9nI.pI756-I762 
Putra, R. D., Rinanto, Y., Dwiastuti, S., \& Irfa, I. (2016). Peningkatan Kemampuan Berpikir Kreatif Siswa melalui Model Pembelajaran Inkuiri Terbimbing pada Siswa Kelas XI MIA I SMA Negeri Colomadu Karanganyar Tahun Pelajaran 2015 / 2016. Proceeding Biology Education Conference, I3(I), 330-334.

Srifujiyati, S., Kamaluddin, K., \& Pasaribu, M. (2018). Pengaruh Model Pembelajaran Inkuiri Terbimbing (Guided Inquiry) terhadap Keterampilan Berpikir Kreatif Siswa SMA Negeri 5 Palu. JPFT (Jumal Pendidikan Fisika Tadulako Online), 6(I), I. Retrieved from https://doi.org/I0.22487/j25805924.20I8.v6.iI.IO0I I

Sudarisman, S. (20I2). Implementasi Model Guided Inquiry dengan Variasi Teknik pada Pembelajaran Biologi di SMA. Prosiding Seminar Nasional MIPA Dan Pembelajaran. Retrieved from_https://doi.org/I3 Oktober 20I2 ISBN 978-602-978956-0

Sukma, Komariyah, L., \& Syam, M. (2016). Pengaruh Model Pembelajaran Inkuiri Terbimbing (Guided Inquiry) dan Motivasi Terhadap Hasil Belajar Fisika Siswa. Saintifika, I8(I), 5963.

Susanti, F. O., Muttaqin, M., \& Listiawati, M. (2017). Pengaruh Model Inkuiri Terbimbing Terhadap Kemampuan Berpikir Kreatif Siswa Pada Materi Sistem Ekskresi. Jurnal BIOEDUIN: Program Studi Pendidikan Biologi, 7(I), 27. Retrieved from https://doi.org/I0.I5575/bioeduin.v7iI.2450

Trianto. (2012). Mendesain model pembelajaran inovatif-progresif. Kencana Prenada Media Group.

Tumurun, S. W., Gusrayani, D., \& Jayadinata, A. K. (2016). Pengaruh Model Pembelajaran Discovery Learning Terhadap Keterampilan Berpikir Kreatif Siswa Pada Materi Sifat-Sifat Cahaya. Jurnal Pena Ilmiah, I(I), IOI-IIO. Retrieved from https://doi.org/I0.23819/pi.vIiI.2936

Yunianta, T. N. ., Rusilowati, A., \& Rochmad. (2012). Kemampuan Berpikir Kreatif Siswa Pada Implementasi Project-Based Learning Dengan Peer and Self-Assessment. In Unnes Journal of Mathematics Education Research, I(2). 